\title{
The current state of civic literacy of schoolchildren: research materials of Moscow education
}

\author{
Andrei Sorokin ${ }^{1 *}$, Anastasiia Polovnikova ${ }^{1}$, Victor Kirillov², Galina Kalabukhova ${ }^{1}$, and \\ Natalia Maslova ${ }^{1}$ \\ ${ }^{1}$ Moscow City University, Institute of Humanities, Department of Teaching Methods of History, \\ Social Studies and Law, Moscow, Russia \\ ${ }^{2}$ Moscow City University, Institute of Humanities, Moscow, Russia
}

\begin{abstract}
Today, it is decisive to determine educational trends for the long-term development of both states and societies. The $21^{\text {st }}$ century proposed fundamentally new approaches to setting educational goals and achieving educational results. An important step towards addressing this issue was the introduction of the " $21^{\text {st }}$ Century Skills" concept. One of its elements is "Cultural and civic literacy". Thus, the international community has made an effort to conduct research in the field of citizenship education. The study aims at forming a comprehensive understanding of the content and assessing the formation of civic literacy by various subjects (in this case, participants in the educational process in the city of Moscow). The selection of research methods and the development of research tools are based on the conceptual provisions in the field of functional literacy. The research novelty is associated with the adoption of innovative international methods by Moscow educational organizations. The study results can be presented in the form of three blocks: a block that determines the level of knowledge and understanding of civic literacy; a block that describes the preconditions and current formation of civic literacy in Moscow educational institutions; a block that represents the self-assessment of civic literacy among participants in the educational process. The study results prove that the respondents demonstrate a fairly high level of proficiency in basic civic terms in the field of knowledge and understanding. This fact correlates with their level of self-esteem. According to the respondents, the necessary conditions for mastering civic literacy are systematic citizenship education at school, the formation of legal culture in families, and the availability of the Internet. Keywords: functional literacy, teaching methods, educational research, civic education.
\end{abstract}

\section{Introduction}

The current development of national education systems is largely determined by the " $21^{\text {st }}$ Century Skills" concept. The structure of its components has been developing over a long

\footnotetext{
*Corresponding author: sorokinaa@mgpu.ru
} 
period. Many scholars note that reading and mathematical literacy was enough to start working in the past, but "now these skills are just a starting point on the path to mastering the $21^{\text {st }}$ century skills" [1].

First of all, we should dwell on the structure of the $21^{\text {st }}$ century skills presented by the international community in 2013. The main component of this concept is the need to form certain personality traits and competencies of students (namely, critical thinking, creativity, communication, and collaboration). This structure also presents a set of basic literacy skills (fundamental knowledge) obligatory for a modern person [1], including "Cultural and civic literacy". In Russia, this component of the $21^{\text {st }}$ century skills is often called "civic literacy". The above-mentioned structure is based on the years-long search for new educational trends. In 1980, US teachers suggested to add the discipline "Critical Thinking" into curricula and characterized it "as an important element of civic literacy" [2].

It would be a mistake to compare the significance of various literacy types. There are a lot of scientific works on the importance and uniqueness of each type of literacy. Scholars highlight that "civic engagement is crucial for building a healthy community... Many studies prove that improved civic literacy and social empathy determined the higher level of civic participation" [3]. Such studies include local, regional, national, and international research of civic literacy formation.

The article presents results and materials of the study in the field of civic education that had been conducted in Moscow for several years. Since the " $21^{\text {st }}$ Century Skills" concept represents a certain innovation in education, the whole research is characterized by certain novelty. Those scholars who study this issue draw attention to the fact that the ICCS 2016 results show that "generally, the European youth tends to be tolerant but their attitude towards equal rights [...] varies both within European educational systems and among them" [4].

This article hypothesizes that the formation of civic literacy in Moscow correlates with the general trends identified by national and international studies. This study should promote the issue under consideration.

The study should comprehensively examine the content and assessment of forming civic literacy by participants in the educational process in the city of Moscow.

The article aims at fulfilling the following tasks:

- To determine the level of knowledge and understanding of civic literacy.

- To describe preconditions and methods for forming civic literacy.

- To reveal the self-assessment of civic literacy by different participants in the educational process (students, teachers, and parents).

\section{Methods}

When selecting research methods and forming appropriate research tools, we referred to conceptual provisions of conducting research in the field of functional literacy. Thus, G.S. Kovaleva derived these conceptual provisions from different definitions of functional literacy. She concluded, "We need to highlight the main elements [...] on whose basis it is possible to develop tools for the formation and assessment of functional literacy. Such elements are the person's ability to act in modern society and solve various problems using knowledge, skills, and abilities" [5]. This conclusion proceeds from the years-long research conducted by the international community and the accumulated Russian experience $[6,7]$.

The research takes into account Russia's participation in the international civic and citizenship study [8]. When defining substantive aspects of the study, we also considered a unique national experience in the field of citizenship education. Thus, the research conducted in Moscow was based on five main points for assessing the level of literacy 
formation in the field of civic education: "civic knowledge, civic skills, understanding of social processes, civic inclinations, skills of civic activity and civic behavior" [9-14].

\section{Results}

The study was conducted in educational institutions (schools and colleges) in 2017-2020. Each stage of the study comprised about 500 participants, including students, teachers, and parents.

A large number of tasks aimed at determining the level of knowledge and understanding in the field of civic literacy. They were developed for analyzing real-life situations, which corresponds to methods of international research. For example, there was a task to consider a proposed situation and decide whether it violates the rules of a democratic state. The ratio of the correct answers provided by the respondents is presented in Figure 1 [15].

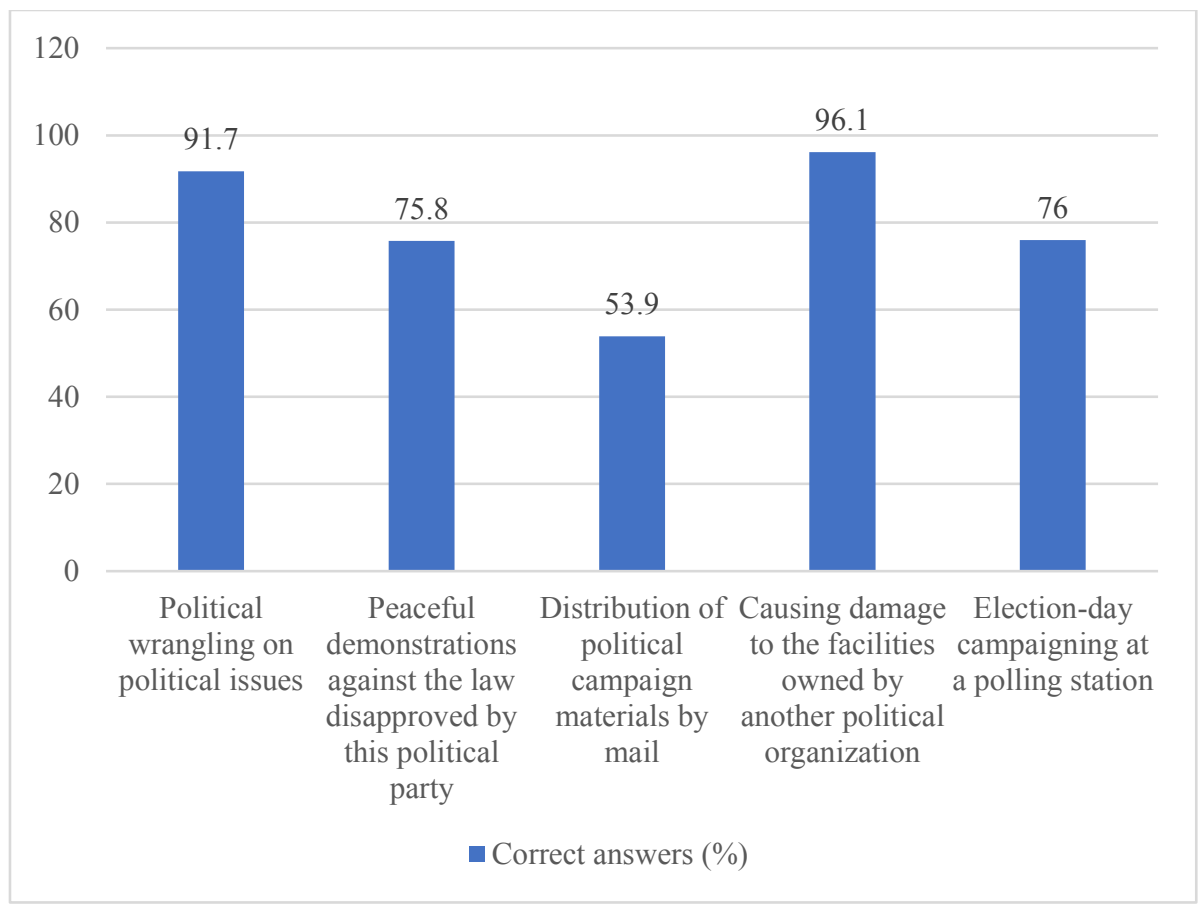

Fig. 1. The respondents' interpretation of a provided situation as offensive or non-offensive in a democratic state.

Thus, the respondents from Moscow educational institutions demonstrated good results when answering the above-mentioned questions.

A separate aspect of the study was associated with the understanding of the related terms, their recognition, and the respondents' self-assessment in relation to their knowledge and understanding of certain terms that underlie civic literacy. The study results revealed that the respondents put a high value on their knowledge of civic terms. Up to $80 \%$ of the respondents noted that they knew the meaning of the terms contained in the task and could explain them. More than $20 \%$ of the respondents stated that they understood most of the terms. However, the term "ombudsman" caused certain difficulties, i.e. more than $65 \%$ of the respondents answered, "I do not know what it is" (Fig. 2) [15]. 


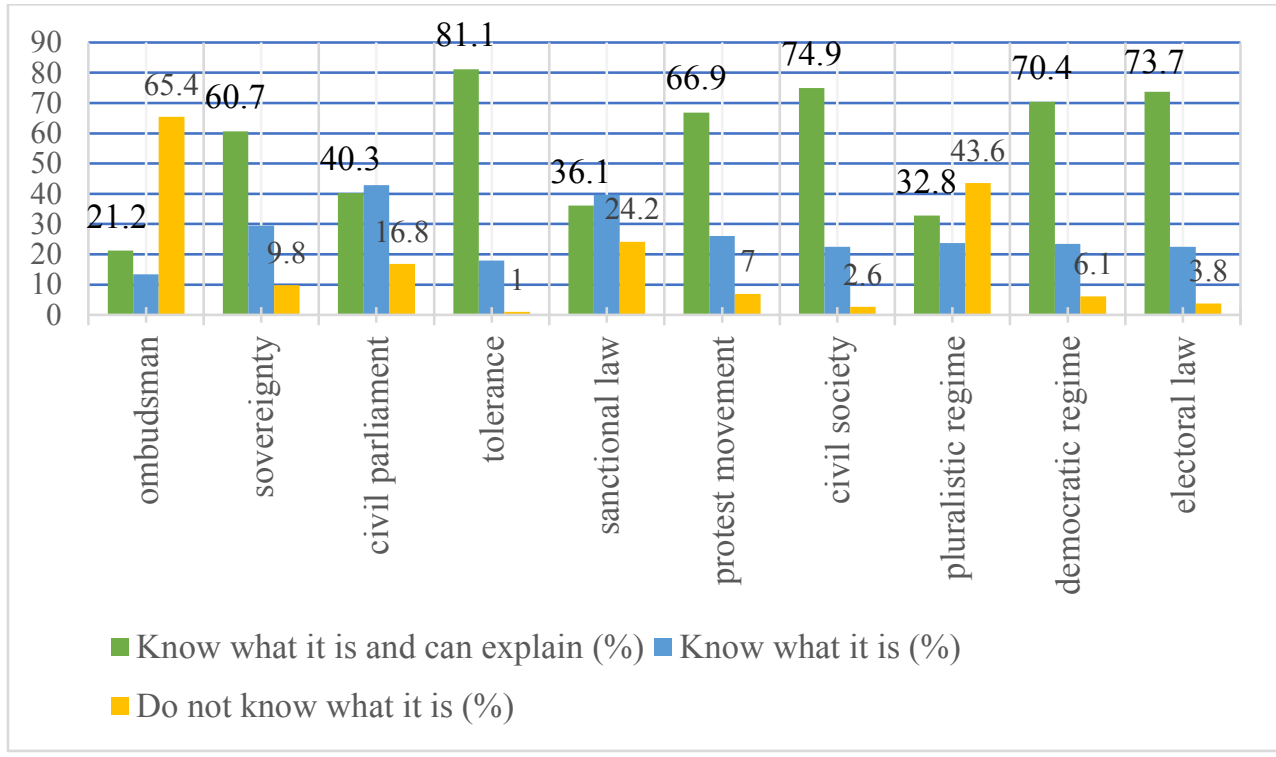

Fig. 2. The respondents' self-assessment of their knowledge of terms in the field of civic literacy.

It is worth mentioning that we included several fictitious terms in our question pool, for example, "sanction law", "civil parliament", and "pluralistic regime". Many respondents considered these terms to be real. We find it alarming that this group of respondents included not only students and their parents but also teachers.

The selected questions aimed at identifying the conditions and existing practices for forming civic literacy in Moscow educational institutions. Most respondents noted that "the issues of civic literacy are discussed rarely or not discussed at all" [16].

In the course of the study, we determined and evaluated the most effective types of work on the formation of civic literacy. They are used in Moscow educational institutions and outside the walls of schools or colleges. The study results are shown in Figure 3. Thus, most respondents responded that civic literacy should be formed in the classroom, family, and by means of the Internet [15]. 


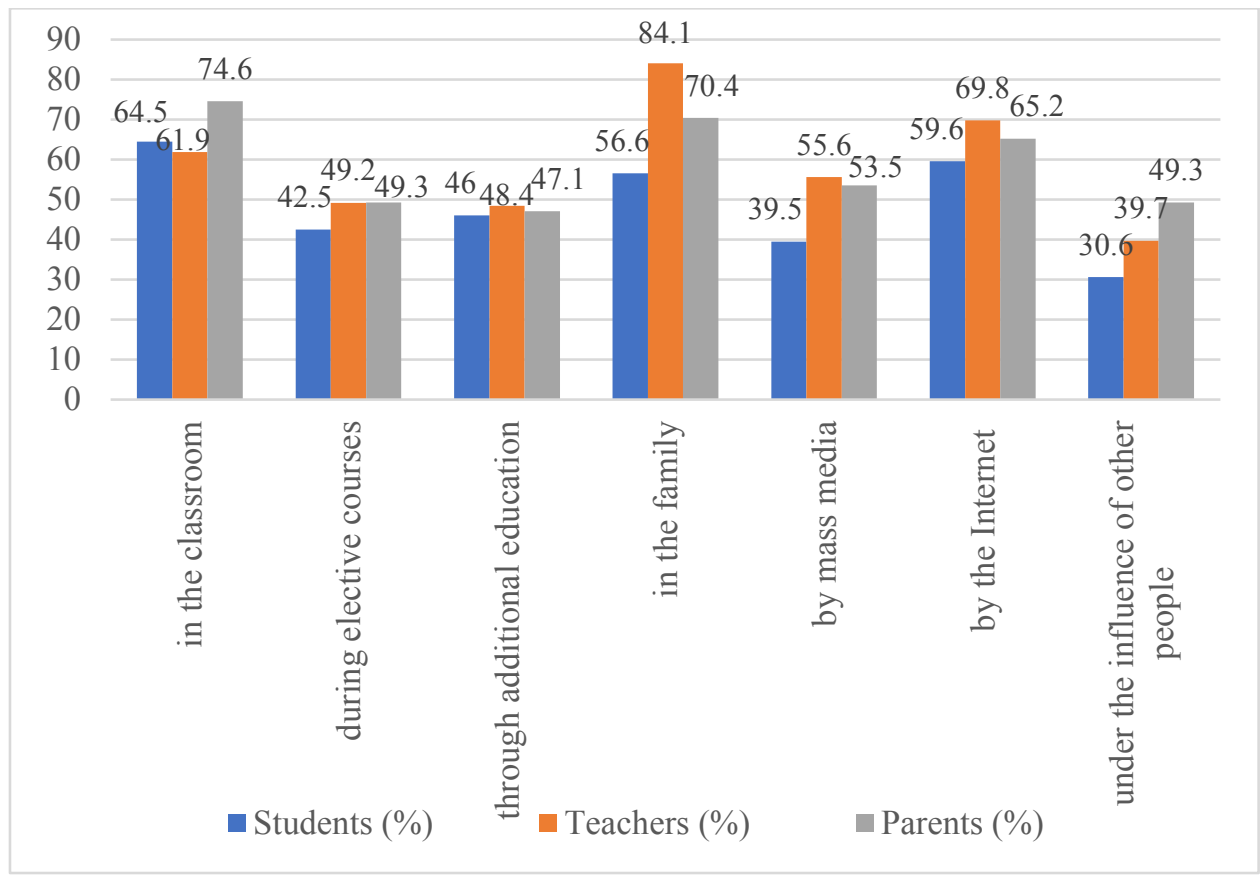

Fig. 3. The respondents' answers to the question about types of work that have a significant impact on the formation of civic literacy.

The final block of questions aimed at identifying the respondents' self-assessment of their level of civic literacy (Fig. 4). According to the study results, $25 \%$ of the respondents assessed their level of civic literacy as high ( 8 or more points on a 10-point scale). Moreover, this group of participants in the educational process comprised the following respondents: every second was a teacher, every third was a parent, and every fifth was a student [15].

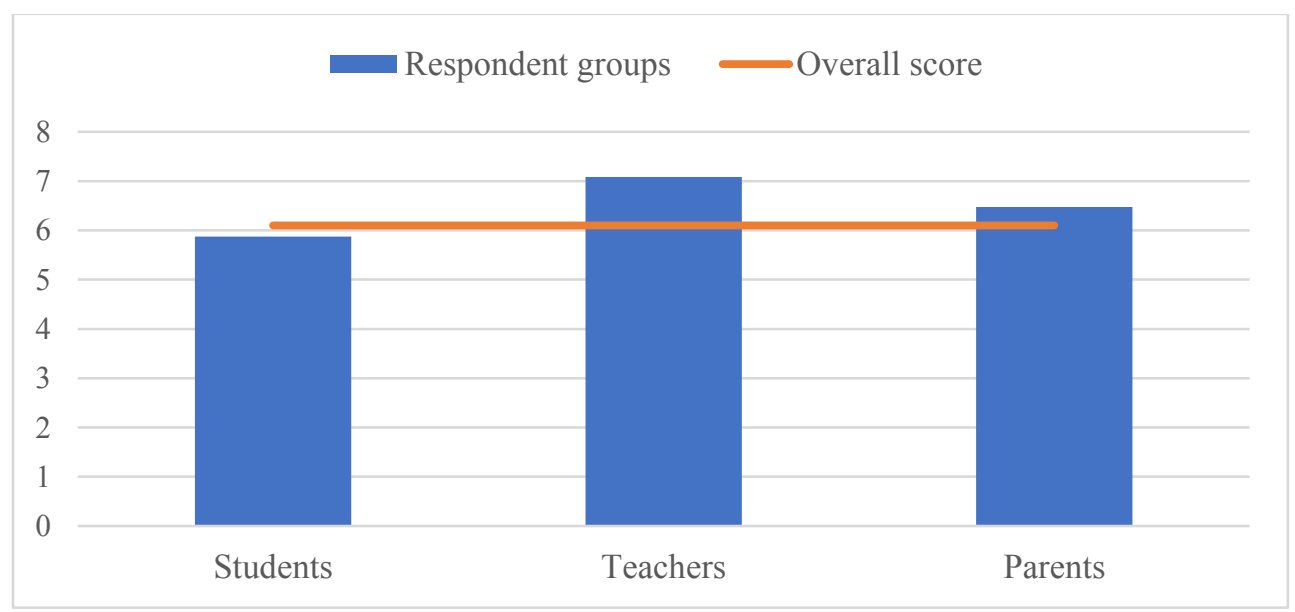

Fig. 4. The respondents' answers to the question about the self-assessment of their knowledge in the field of civic literacy (on a 10-point scale). 


\section{Discussion}

Currently, attempts are made to develop the " $21^{\text {st }}$ Century Skills" concept. We refer to a universal competency and new literacy framework (Fig. 5) [17].
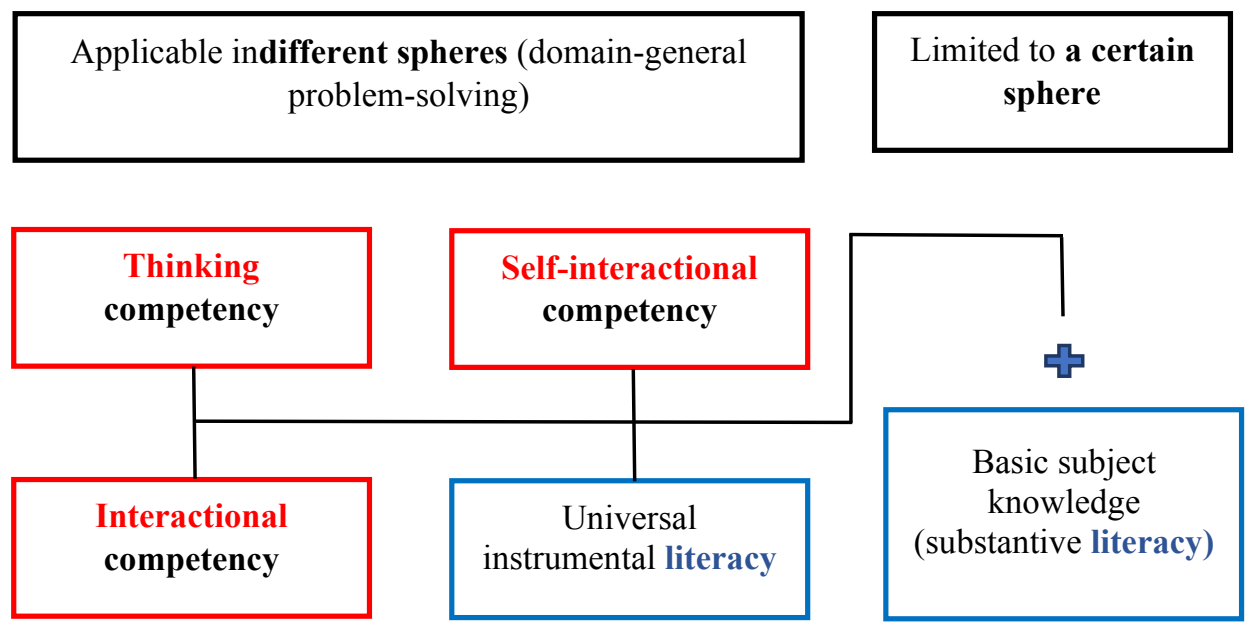

Fig. 5. Universal competency and new literacy framework.

According to the logic of this research, civic literacy is embedded in the "Basic Subject Knowledge" block along with natural science, financial, legal, environmental, and other types of functional literacy.

Modern scholars analyzed a large number of pedagogical works concerned with citizenship education. When analyzing articles posted in the electronic scientific library, we typed in the search query "the formation of civic literacy" and received 108 results as of April 2019, but most of those publications dated to 2016-2019 [18]. The data obtained indicate the relevance of civic education for modern studies.

Both Russian and foreign scholars emphasize that it is necessary to start forming civic literacy from early childhood. Civic literacy should be based on "intergenerational collaboration in learning" [19]. Many scholars state that "civic literacy skills of students remain an underdeveloped area of learning in the field of social sciences" [20].

\section{Conclusion}

Today, it is relevant to study the formation of civic literacy as a component of functional literacy. On the one hand, such studies provide an extensive empirical basis for determining the level of knowledge and understanding of civic literacy, describing conditions and factors that influence the formation of civic literacy, as well as representing the selfassessment of civic literacy among participants in the educational process. On the other hand, the discussion of the results obtained throughout the study generates interest in this issue in society and gives a new impetus to the development of citizenship education.

\section{References}

1. World Economic Forum, New Vision for Education. Unlocking the Potential of Technology (2015). Accessed on: December 16, 2020. [Online]. Available: http://www3.weforum.org/docs/WEF_New_Vision_for_Education.pdf 
2. D. Lazere, Reading and Writing for Civic Literacy. The Critical Citizen's Guide to Argumentative Rhetoric (Routledge, New York, 2017).

https://doi.org/10.4324/9781315089164

3. M.E. Hylton, Journal of Higher Education Outreach and Engagement, 22(1), 87-106 (2018). Accessed on: December 16, 2020. [Online]. Available: https://openjournals.libs.uga.edu/jheoe/article/view/1373

4. E. Claes, M.M. Isac, IEA Compass: Briefs in Education, 9 (2020). Accessed on: December 16, 2020. [Online]. Available: https://www.iea.nl/publications/seriesjournals/iea-compass-briefs-education-series/june-2020-civic-knowledge-and

5. V.S. Basyuk, G.S. Kovaleva, Otechestvennaya i zarubezhnaya pedagogika, 1(4(61)), 13-33 (2019)

6. G.S. Kovaleva, Otechestvennaya i zarubezhnaya pedagogika, 1(2(37)), 31-43 (2017)

7. A.A. Sorokin, A.V. Polovnikova, Prepodavanie istorii i obshchestvoznaniya v shkole, 8, 12-20 (2019)

8. A. Danilina, Uchitelskaya gazeta, 39 (2017). Accessed on: December 16, 2020. [Online]. Available: http://old.ug.ru/archive/71647

9. P. Polozhevets, A. Ioffe, Uchitelskaya gazeta, 30 October (2015). Accessed on: December 16, 2020. [Online]. Available: http://old.ug.ru/appreciator/96

10. P. Polozhevets, Uchitelskaya gazeta, 07 (2018). Accessed on: December 16, 2020. [Online]. Available: http://old.ug.ru/archive/73452

11. P. Polozhevets, Uchitelskaya gazeta, 08 (2018) Accessed on: December 16, 2020. [Online]. Available: http://old.ug.ru/archive/73542

12. P. Polozhevets, Uchitelskaya gazeta, 09 (2018). Accessed on: December 16, 2020. [Online]. Available: http://old.ug.ru/archive/73641

13. P. Polozhevets, Uchitelskaya gazeta, 10 (2018). Accessed on: December 16, 2020. [Online]. Available: http://old.ug.ru/archive/73740

14. P. Polozhevets, Uchitelskaya gazeta, 11 (2018). Accessed on: December 16, 2020. [Online]. Available: http://old.ug.ru/archive/73809

15. G.V. Kalabukhova, V.V. Shapoval, Prepodavanie istorii i obshchestvoznaniya v shkole, 8, 21-27 (2019)

16. G.V. Kalabukhova, Technology of Assessment Educational Activities Outcomes, in Conference of Topical issues of the humanities: theory, methodology, practice, Moscow City University, 3 April 2019, Moscow, Russia (2019)

17. M.S. Dobryakova, I.D. Frumin, Universalnye kompetentnosti i novaya gramotnost: ot lozungov k realnosti [Universal competences and new literacy: from slogans to facts] (Publishing House of Higher School of Economics, Moscow, 2020). https://doi.org/10.17323/978-5-7598-2177-9

18. N.N. Maslova, I.A. Nederman, Civic literacy: approaches to formation, in Conference of Topical issues of the humanities: theory, methodology, practice, Moscow City University, 3 April 2019, Moscow, Russia (2019)

19. M. Hanmore-Cawley, T. Scharf, Journal of Intergenerational Relationships, 16(1-2), 104-122 (2018). https://doi.org/10.1080/15350770.2018.1404421

20. J. Clabough, T. Lintner, No Reluctant Citizens: Teaching Civics in K-12 Classrooms, (Information Age Publishing, Charlotte, 2018) 